\title{
A POÉTICA DA VOZ NO ESPAÇO
}

\section{Olívia Campelo de Freitas*, Rodrigo Spina de Oliveira Castro.}

\begin{abstract}
Resumo
O presente projeto se edificou a partir de uma pesquisa teórico-prática acerca da experimentação da voz e da palavra influenciadas pelo espaço físico e sua semiótica no teatro. O principal foco partiu dos pensamentos de Valère Novarina em Diante da Palavra', mas foi complementado pela análise de outros materiais teatrais, filosóficos e antropológicos acerca da voz. Conforme a pesquisa caminhou, a questão do referencial de escuta se tornou um princípio em relação à temática, e sua sustentação tanto teórica quanto prática exigiu um grande apêndice temporal para se inclinar sobre essa questão. $O$ projeto constituiu-se de pesquisas com atores e um cuidadoso olhar para as referências teóricas, resultando em um ensaio acadêmico somado a uma experiência performativa em instalação artística.
\end{abstract}

\section{Palavras-chave:}

voz, espaço, palavra

\section{Introdução}

Este trabalho utilizou o conceito de poética da voz como expressão sonora através do olhar sobre a fricção entre emissão e preenchimento do espaço físico. Para isso, partimos dos pensamentos de Valère Novarina e Gaston Bachelard2.

A fenomenologia dessa questão vocal foi analisada a partir da compreensão dos conceitos básicos da física do som e da semiologia da voz em relação a todos esses elementos citados.

A arquitetura, o tempo, o imaginário e as transformações de situação foram levadas em conta para que alcançassem uma experiência da vocalidade em site specific.

O material de pesquisa reunido na bibliografia comporta pensamentos de algumas áreas que foram trazendo acréscimos essenciais nas dúvidas, descobertas e debates. Um exemplo é a obra da filósofa Adriana Cavarero $^{3}$, uma das principais referências no processo, que põe em debate o histórico de generalização da voz, isto é, a falta de devida atenção ao que também caracteriza uma individualidade.

É importante ressaltar uma questão-chave da metodologia: a busca de autonomia no aprendizado dos participantes. Como pesquisadora, coube apresentar pensadores do assunto e suas abordagens, mas flexibilizar os caminhos individuais.

O objetivo deste projeto foi a pesquisa conjunta a um grupo de atores, focado na percepção do espaço como elemento fomentador da poética vocal da cena e que visava chegar a uma experiência prática, que chegou no formato de uma performance-instalação. Os encontros ao longo do ano foram preparados com base na bibliografia e combinado com as potências encontradas durante 0 processo. Algumas referências foram abordadas de forma direta e outras em forma de analogia. Mas tudo isso concentrado em uma relação principal: a voz e o espaço.

\section{Resultados e Discussão}

- O referencial de escuta como essencial na pesquisa da emissão vocal: Houve um grande impasse dentro do grupo prático para que a voz fosse utilizada em improviso livremente, especialmente em locais públicos. Não havia uma confiança plena porque os atores não haviam praticado a escuta de forma a refiná-la e construir um jogo conjunto. Outros dois pontos foram reconhecidos a partir disso:

1. Para uma escuta interna de si, um ambiente reservado e favorável acusticamente se mostrou importante para o andamento do estudo;

2. Existe uma premissa fundamental na física do som; que sua existência só é considerada real porque há quem a ouça. Portanto, a existência da emissão exige uma mínima atenção da escuta, nem que seja em forma de vibração. - O reconhecimento da unicidade da voz: porque é produzida em um corpo e ressoa em um espaço. Ambos com suas especificidades físicas.

- A voz que conhece sua unicidade possui certamente também a escuta interna e externa. Elas não estão ou surgem sozinhas, mas junto com a situação da cena (situação ficcional, por exemplo) e de fora da cena

(arquitetura/ambiente), porque não podemos esquecer que o teatro é sempre "o presente do presente. A capacidade de conhecer e habitar este presente" (FABIÃO, 2010, p. 322, grifos da autora $)^{4}$.

- O estudo do que antecede a palavra - a voz como sonoridade. Ser significante antes de significado.

\section{Conclusões}

Este estudo trouxe uma compreensão essencial sobre a voz no teatro: existem aspectos que vão além da função tradicional da voz na performance (meramente a preocupação com a inteligibilidade das palavras) que são de extrema relevância, porém tratados muitas vezes com pouca importância no desenvolvimento do ator. Reservado um tempo de reconhecimento do universo vocal, de suas possibilidades e outros referenciais, é aberto um extenso caminho criativo na área.

\footnotetext{
${ }^{1}$ Novarina, V. Diante da Palavra. 7Letras. 2009

2 Bachelard, G. A Poética do Espaço. Martins Fontes. 1989

${ }^{3}$ Cavarero, A. Vozes Plurais: Filosofia da Expressão Vocal. Editora UFMG 2011

${ }^{4}$ Fabião, E. Corpo Cênico, Estado Cênico. In. Revista Contrapontos. 2018
} 